\section{En enkel og kortfattet bok om (medisinske) feil}

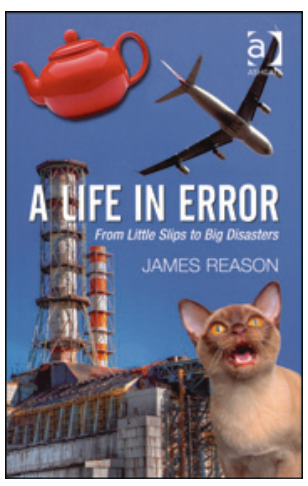

James Reason

A life in error

From little slips to big disasters. 133 s, ill.

Farnham: Ashgate Publishing, 2013.

Pris GBP 13

ISBN 978-1-4724-1841-8

Psykologen James Reason har gjennom de siste 20 årene vært en av de mest innflytelsesrike tenkerne innenfor pasientsikkerhet. Hans forskning på «human factors» feil og utilsiktede hendelser har vært banebrytende, ikke minst innenfor helsevesenet. Denne boken oppsummerer hans reise og forskning innenfor feltet. Det er en lettlest og veldig god bok som alle fra studenter til de som sitter til ledelsen i helseforetak og byråkratiet, vil ha glede av.

Det er en kort tekst, som ikke går i dybden på noen temaer, men som gir en god oversikt over feltet feil, både fra et individuelt og fra et organisatorisk perspektiv. Det finnes mange referanser for dem som ønsker å lære mer, og det er flere av James Reasons bøker som burde vært obligatoriske for leger. Boken er ikke myntet på helsepersonell spesielt, men de siste kapitlene er viet medisinske feil, da dette har vært forfatterens interesseområde de siste årene. Språket er levende, og eksemplene er varierte og gode.

Kapittelinndelingen er oversiktlig; den første delen av boken handler mest om individet, mens organisasjoner og systemer vies mer plass i de siste kapitlene. Forfatteren reflekterer over hvor langt vi har kommet i pasientsikkerhetsarbeidet, og refleksjonene gir ettertanke. Han trekker frem helsevesenets kompleksitet og den store mangelen på undervisning om og kompetanse innenfor risiko, systemforståelse og det å unngå «naming, shaming and blaming». Å gjøre feil er vanskelig for oss leger, konsekvensene er store, og vi vet ikke så mye om hvordan vi sammen kan lære av dem. Denne boken gir ingen verktøy i så måte, men den gir både begreper og forklaringer som i det minste gjør det enklere å snakke om feilene. Les den!

\section{Jo-Inge Myhre}

Turnuslege, Raufoss kommunelegekontor Gjøvik

\section{Tiden etter kirurgi - mest for sykepleiere}

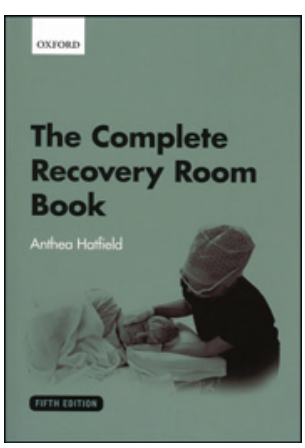

Anthea Hatfield

The complete recovery room book

5. utg. 592 s, tab, ill Oxford: Oxford University

Press, 2014. Pris GBP 40

ISBN 978-0-19-966604-1

Denne boken omhandler oppvåkning (recovery) etter kirurgi. Den henvender seg i hovedsak til sykepleiere som arbeider i slike enheter. Anestesileger og kirurger kan også ha nytte av å lese en samlet fremstilling av problemer i denne delen av pasientforløpet som ofte har liten plass i spesialistenes kjernepensum.

Boken ble første gang utgitt i 1992. Den er bygd opp med 30 frittstående kapitler, alle skrevet av samme forfatter. Hoveddisposisjonen i kapitlene er først å presentere basal fysiologi, deretter praktiske aspekter. Teksten er oversiktlig presentert, med god bruk av oppsummerende faktabokser. Bildene er ikke av samme kvalitet; sort-hvitt og dårlig fokus, og de bærer preg av å ha overlevd for mange nye utgaver. Det er få referanser etter hvert kapittel, hovedsakelig tidsskriftreferanser, ingen nettressurser.

Boken innledes med kapitler om «recovery»-enhetens rutiner, design og monitoreringsutstyr. Deretter kommer tre kapitler om smertebehandling. Disse beskriver en praksis i tråd med skandinavisk tradisjon, selv om medikamentvalget avviker noe. Kapitlet om postoperativ kvalme og oppkast anbefaler antihistaminer i større grad enn det som er vanlig i Norge. Ingen referanser er angitt for dette. Gode, nyere konsensuspublikasjoner om problemet burde vært med i referanselisten.

Deretter omtales «recovery»-fasen og potensielle problemer hos forskjellige pasientgrupper, som barn, obstetriske pasienter, hjertesyke, lungesyke, traumepasienter og så videre. Disse kapitlene gir gode oversikter, men erstatter ikke spesiallitteratur.

Siste del inneholder et godt kapittel om kommunikasjon, kulturelle forhold og uheldige hendelser. Boken avsluttes med en enkel innføring i statistiske begreper.

Jeg mener denne utgivelsen kan være en god bok for sykepleiere $\mathrm{i}$ «recovery»-enheter. Norske lærebøker i intensiv- og anestesisykepleie har lite fokus på denne fasen av det perioperative forløpet.

\section{Sigurd Fasting}

Avdelingsoverlege, Anestesiavdelingen St. Olavs Hospital 